\title{
THE USE OF DROUGHT-INDUCED "CROP LINES" AS A TOOL FOR CHARACTERIZATION OF KARST TERRAIN
}

\author{
Samuel V. Panno \\ Illinois State Geological Survey, 615 E. Peabody Drive, Champaign, Illinois 61821, USA, s-panno@illinois.edu
}

Donald E. Luman

Illinois State Geological Survey, 615 E. Peabody Drive, Champaign, Illinois 61821, USA, luman@illinois.edu

\section{Walton R. Kelly}

Illinois State Water Survey, 2204 Griffith Drive, Champaign, Illinois 61820, USA, wkelly@illinois.edu

\section{Matthew B. Alschuler}

PO Box 325, Warren, Illinois 61087,USA, matthew@cottonexpressions.com

\begin{abstract}
The persistent drought of the 2012 summer in the Midwestern United States significantly impacted the health and vigor of Illinois' crops. An unforeseen outcome of the extreme drought was that it provided a rare opportunity to examine and characterize the bedrock surface and underlying karst aquifer within the Driftless Area of northwestern Illinois. Complex networks of vegetated lines and polygonal patterns, herein referred to as crop lines, crisscrossed the dry summer landscape of Jo Daviess County. Initially, the crop lines were examined and photographed using a handheld digital camera on the ground and from a small aircraft at 300 meters altitude above ground level (AGL). The orientations, widths and horizontal separations of the lines were measured. Crop lines and their patterns and orientations were compared with those of crevices in outcrops, road cuts and quarries, and with lineaments seen in LiDAR elevation data of Jo Daviess County.
\end{abstract}

Primarily confined to alfalfa fields and, to a lesser extent, soybeans and corn, the crop lines are the result of a combination of extremely dry conditions, and a thin soil zone overlying fractured and creviced Galena Dolomite bedrock. The plants forming the lines tend to grow denser, taller $(0.5 \mathrm{~m}$ vs $0.15 \mathrm{~m})$ and darker/ greener than those in adjacent areas. Alfalfa taproots are the deepest of the aforementioned crops extending up to $7 \mathrm{~m}$ below the surface. Groundwater and associated soil moisture within the vadose zone present within bedrock fractures and crevices provide the necessary moisture to sustain the overlying healthy plants, while the remaining area of the field exhibits stunted and sparse plant growth.
Overall, the crop lines are a reflection of the creviced pattern of the underlying karst bedrock and associated karst aquifer, and reveal the degree and extent of karstification in eastern Jo Daviess County. The crop lines were consistent with the angular lines of adjacent streams that show a rectangular drainage pattern. Stream patterns like these are well known and are due to drainage controlled by crevice/fracture patterns in the top of bedrock. The lines appear to have been formed by two sets of fractures trending roughly northsouth and east-west with occasional cross-cutting fractures/ crevices. The east-west trending lines are consistent with tension joints, and the north-south lines are consistent with the shear joints identified by earlier researchers. The trends of the crop lines, tension and shear joints are similar to those of lineaments identified from LiDAR elevation data in the same area $\left(\mathrm{N} 20^{\circ} \mathrm{W}\right.$, and $\mathrm{N} 70^{\circ} \mathrm{W}$ and $\left.\mathrm{N} 70^{\circ} \mathrm{E}\right)$ and coincide with the occurrence of karst features throughout eastern Jo Daviess County.

The pattern observed in the crop lines closely mimics the fracture/crevice patterns of the bedrock surface. The widths and extent of the lines may be used as a surrogate for the karst features present on the bedrock surfaces. Crop lines, coupled with solution-enlarged crevices seen in bedrock exposures, yield a three dimensional view of the bedrock crevice-fracture system, and ultimately could provide a more complete and accurate model of the karst aquifer in the study area and similar karst areas in the Midwestern United States and perhaps in other karst regions of the world.

\section{Introduction}

Carbonate rock at or near the surface are fractured and typically creviced due to solution enlargement to the point 
where the rock body constitutes a karst aquifer (Quinlan et al. 1991). These fractures and crevices are usually covered with fine-grained sediment. Consequently, the fractures and crevices in the bedrock are only observed in excavations, road cuts, quarries, outcrops and rarely where the soil and sediment overlying the bedrock surface has been denuded by erosion. However, in areas where soils are thin and during extremely dry periods and where crops are planted, lines in the vegetation (hereafter referred to as "crop lines") have been observed in the Wisconsin Driftless Area (Maureen Muldoon, University of Wisconsin, personal communications, 2011). It is likely that these lines mirror the fracture/crevice patterns of the underlying bedrock carbonate aquifer.

Unfortunately, the reporting of these occurrences is usually only anecdotal, and documentation is difficult to find because of their ephemeral nature which may be only weeks or a few months. However, in rare cases, researchers succeed in capturing short-lived phenomena. Extreme drought conditions in Illinois and in the surrounding states in the 2012 summer created a rare situation that has resulted in the formation of vivid lines and patterns in crops in Jo Daviess (Figure 1) and surrounding counties in northwestern Illinois' Driftless Area. The crop lines
(Figure 2) occurred in the thin soils of the Driftless Area overlying the carbonate bedrock of the eastern two thirds of Jo Daviess County, the western portion of Stephenson County and well into southern Wisconsin.

The objectives of this investigation were to document the crop lines observed in eastern Jo Daviess County, Illinois, and assess their usefulness as indicators of karstified carbonate bedrock that may be associated with a karst aquifer. Because the crop lines appear to accurately mimic the creviced surface of the underlying karst bedrock, we explored their usefulness in identifying the extent, character and geometry of the underlying karst aquifer.

\section{Methods}

The authors were contacted by a Jo Daviess County resident on July 16, 2012 concerning the appearance of crop lines in the Driftless Area of northwestern Illinois. We conducted a reconnaissance trip to eastern Jo Daviess County on July 19 during which time we examined and photographed abundant crop lines on the ground, as well as from a low-altitude aircraft using a handheld camera. The initial photography was used to secure funding for additional trips to the site.

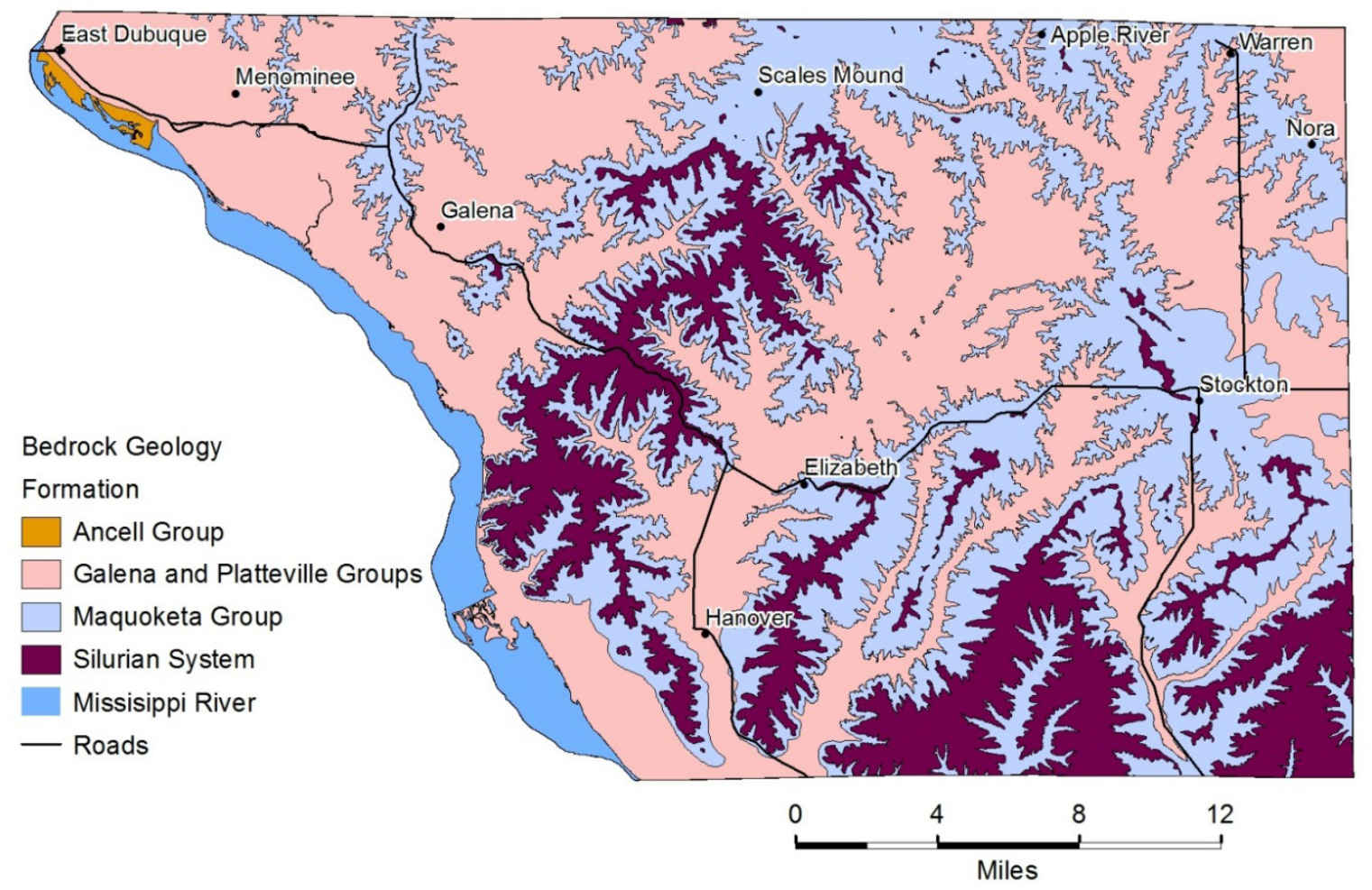

Figure 1. Generalized geologic map of Jo Daviess County (modified from McGarry 2000). 


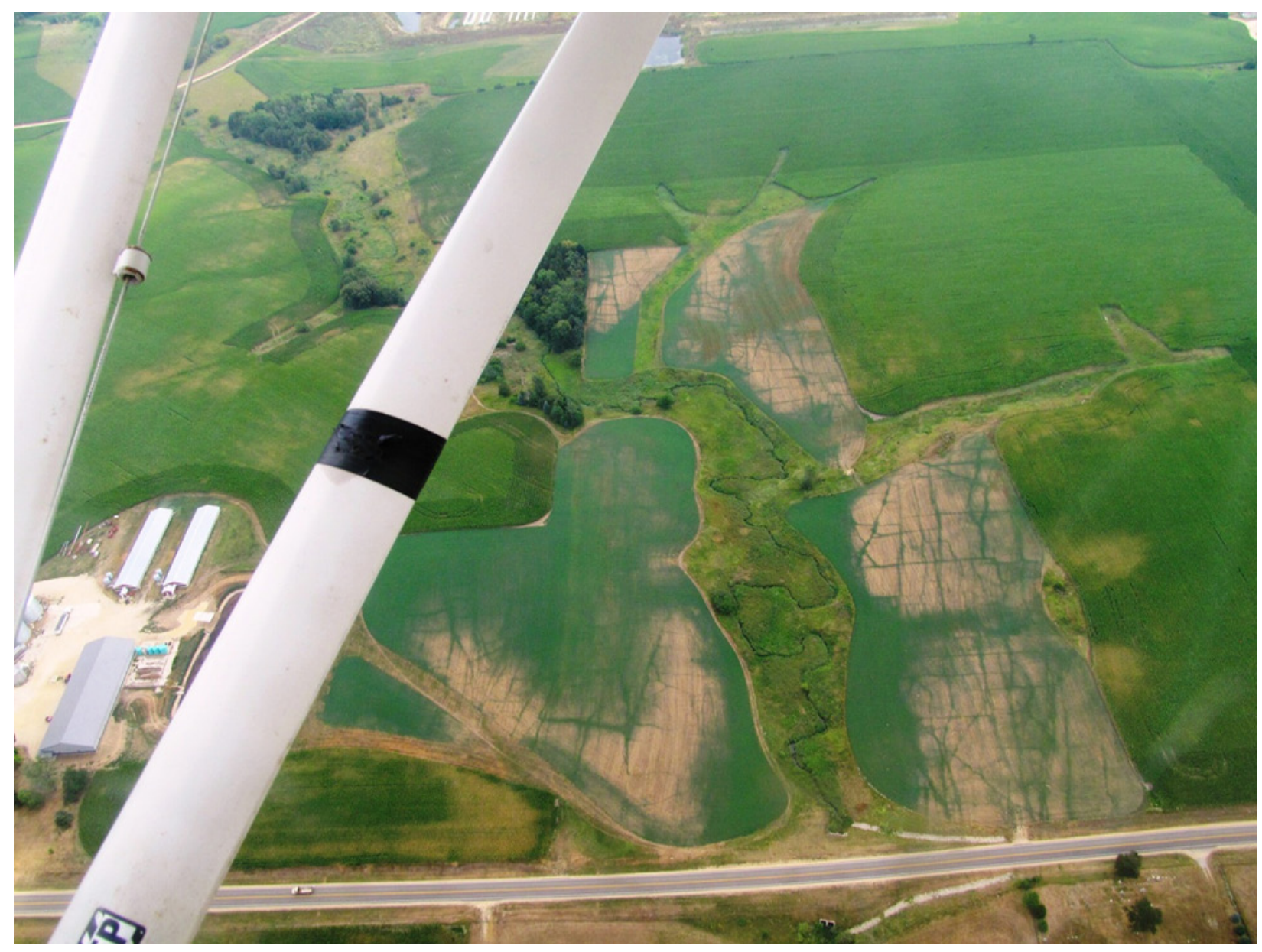

Figure 2. Alfalfa fields reveal the geometry and character of the underlying karstified Galena Dolomite. Crevice-controlled rectangular stream patterns are also apparent. This oblique aerial photograph was taken 4.0 $\mathrm{km}$ south of Warren, IL in Jo Daviess County.

A subsequent low-altitude reconnaissance flight was conducted one month later to document additional occurrences and estimate the geographic extent of the crop lines in Jo Daviess County. Based upon this information, a request was made to the Illinois Department of Transportation, Aerial Survey Division to acquire vertical aerial photography for 16 selected sites using a 9"x9" mapping camera. However, due to weather issues, aerial photographs were not taken until August 28 and 29. Soon after the IDOT aerial photography acquisition, the area experienced increased rainfall and harvesting began earlier due to the drought. The combination of these two factors resulted in the crop line features disappearing or being eliminated.

Soil depths were measured in lined fields using a soil probe and a tape measure. Vegetation that created the crop lines was examined on the ground and from aerial photography. The widths, orientations and spacing of the crop lines were documented and compared with those of crevices and fractures in exposures, and with lineaments seen in LiDAR elevation data of Jo Daviess County (Panno et al. in review). All imagery and field data were examined and compared with information gleaned from existing bedrock exposures as described by Bradbury (1959), Heyl et al. (1959), and Panno et al. (in review).

\section{Results and Discussion Geology of Jo Daviess County}

Jo Daviess County (Figure 1) lies within the Driftless Area of northwestern Illinois; the county lacks glacial drift that covers the bedrock of most of the upper Midwestern U.S. (Hansel and McKay 2010). Bedrock in this county consists of Middle-Ordovician (443 - 490 Ma) carbonate rocks of the Galena-Platteville Group, thin remnants of the Ordovician age Maquoketa shale, 
and Silurian-age (412 - $443 \mathrm{Ma})$ dolomite that constitutes much of the highlands in the county.

Tectonic compression and extension occurred in this area during and following the formation of the Wisconsin Arch that began in Cambrian time (490 - $543 \mathrm{Ma})$ and continued to be active in late Silurian or Devonian time (354 - $417 \mathrm{Ma})$ (Nelson 1995). The Wisconsin Arch, in part, separates the Illinois Basin to the south from the Michigan Basin to the east. The Mississippi River Arch separates the Illinois Basin from the Forest City Basin to the west. Jo Daviess County lies on the southwestern flank of the Wisconsin Arch (Frankie and Nelson 2002). As a result of the compression and extension, bedrock along the Wisconsin Arch has a well-developed vertical joint system. Heyl et al. (1959) identified that "All the rock formation in the district [most of Jo Daviess County] contain well-developed vertical and inclined joints. The vertical joints are traceable for as much as $3.2 \mathrm{~km}$ horizontally, and for as much as $100 \mathrm{~m}$ vertically. Joints are especially well developed in the Galena dolomite." Heyl et al. (1959) identify three groups of joints: tension joints trending E-W to $\mathrm{N} 65^{\circ} \mathrm{W}$, and two sets of shear joints trending $\mathrm{N} 20^{\circ}-30^{\circ} \mathrm{E}$ and $\mathrm{N} 20^{\circ}-30^{\circ}$ W. Bradbury (1959) found that crevice orientations in numerous exposures in far eastern Jo Daviess County trend $\mathrm{N} 85^{\circ}-90^{\circ} \mathrm{W}$ (nearly E-W) and $\mathrm{N} 02^{\circ}-18^{\circ} \mathrm{W}$.

Solution-enlarged crevices also acted as foci for ore mineralization in this area. The geology of the Upper Mississippi Valley Zinc-Lead District, which includes Jo Daviess County and extends into Iowa and Wisconsin, has been summarized by Heyl et al. (1959) and Bradbury (1959). Lead- and zinc-bearing ore minerals were mined from this area between the late 1700s and 1973. Primary ore mineralization was found in solution-enlarged crevices or in solution cavities in carbonate rocks of the Galena Group called "gash-vein deposits." Galena $\left(\mathrm{PbS}_{2}\right)$ was the main ore mineral in these deposits, and sphalerite $\left(\mathrm{ZnS}_{2}\right)$ was the most abundant ore mineral associated with bedding planes and reverse faults (Heyl et al. 1959). For these types of ore deposits, hydrothermal fluids (hypersaline brines) carrying lead and zinc in solution were implicated as the source of the mineralization by various geochemical and isotopic indicators within the ore and associated minerals. Oreforming solutions originating from evaporative brines associated with the Reelfoot rift system (late Paleozoic time) is one of the more recent hypotheses proposed to explain the origin of these deposits (Rowan and de Marsily 2001). Ore mineralization and dolomitization of the Ordovician-age carbonate rocks of this district have been dated by several techniques as Early Permian in age ranging between 270 and 280 Ma (Brannon et al. 1992; Pannalal et al. 2004).

Recent work by Panno et al. (in review) expanded on our understanding of the karst terrain of Jo Daviess County first identified by Weibel and Panno (1997). Examination of the LiDAR elevation data revealed numerous lineaments in eastern Jo Daviess County (Figure 3). Lineaments identified from aerial photography have been used since the early 1950s for oil, gas, and mineral exploration. Lattman and Parizek (1964) and Parizek (1976) extended this work to groundwater resources by identifying and examining major lineaments to define zones of increased weathering, porosity, and permeability within carbonate rock. Specifically, Lattman and Parizek (1964) state that "Fracture traces and lineaments appear to be universal in their distribution and will have their greatest utility in rocks where secondary permeability and porosity dominate and where intergranular characteristics combine with secondary openings influencing weathering, and soilwater and groundwater movement." The lineaments in Jo Daviess County consisted of the alignment of numerous, unusually-oriented stream valleys across the study area. Many stream valleys are linear, while others have sharply angular meanders. These angular features or rectangular patterns are classic geomorphologic indicators and strongly suggest bedrock control of the streams in the study area (Figure 2).

The lineaments in the study area have three distinct trends; approximately $\mathrm{N} 20^{\circ} \mathrm{W}, \mathrm{N} 70^{\circ} \mathrm{W}$, and $\mathrm{N} 70^{\circ} \mathrm{E}$. Examination of sinkholes in eastern Jo Daviess County revealed individual sinkholes and en echelon sinkholes, all of which are coincident with lineaments. Examination of mapped lineaments in far eastern Jo Daviess County revealed that every lineament had one or two sinkholes in close proximity to one another and to the streams. Sinkholes in this area were typically $0.5 \mathrm{~m}$ to greater than $1 \mathrm{~m}$ deep and about $1 \mathrm{~m}$ in diameter. Larger sinkholes up to $10 \mathrm{~m}$ in diameter were also found. Features that were often found associated with the sinkholes were steep-sided, partially water-filled indentations along the stream bank that extended 1.6 to $5 \mathrm{~m}$ into the 


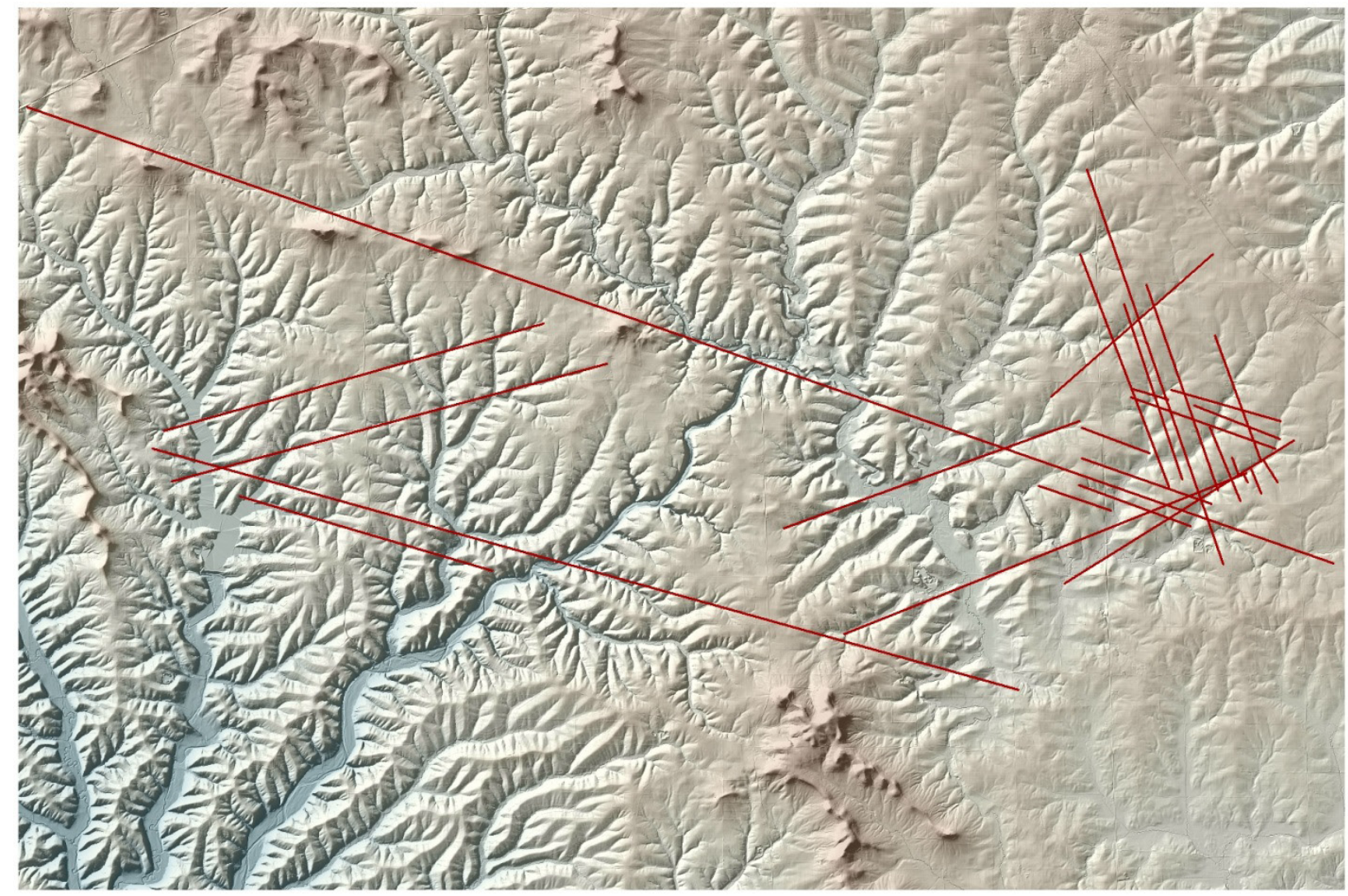

Figure 3. LiDAR shaded relief image of eastern Jo Daviess County showing lineaments and their orientations (from Panno et al. in review).

bank. In addition, the stream orientation tended to shift abruptly and follow the trend of the lineament where they crossed streams instead of having the more typical gently curved meanders. These angular stream features had similar orientations to the mapped lineaments and reflect bedrock control. On the basis of these data, the lineaments identified on the LiDAR maps are interpreted to be a reflection of open crevices in the underlying carbonate bedrock aquifer that are transmitting groundwater. Examination of the geomorphology of the stream valleys suggests that the lineaments are linear depressions that formed along solution-enlarged crevices. These depressions probably form where overlying sediment becomes thinner with proximity to stream valleys where carbonate bedrock is exposed in the stream floor. Lineaments in carbonate rock terrain have been found to be indicative of zones of enhanced well yields; that is, the use of lineaments (only) in locating highproductivity wells in carbonate terrain has had a success rate of 75 to $80 \%$ (R. Parizek, Pennsylvania State University, personal communications, 2009).

\section{Crop Lines}

The 2012 summer drought that affected the health and vigor of crops of the Midwestern United States and thin soils provided an opportunity to view the geology of the underlying carbonate bedrock in the Driftless Area of Illinois. Less than $8 \mathrm{~m}$ of soil and unconsolidated materials overlie the fractured and creviced carbonate bedrock of Jo Daviess County, northwestern Illinois (Riggs and McGarry 2000). Measurements of soil thickness in the areas between the crop lines at one field ranged from 0.6 to $1.2 \mathrm{~m}$. Soil thicknesses immediately over the lines were typically greater than $1.5 \mathrm{~m}$. Excavation of the lines revealed that many contained clays that were visually and texturally identical to the weathering product of Maquoketa Shale. The depth of the clays within the crevices was at least $3 \mathrm{~m}$ for the few crevices examined. The wetness and presence of water within the clays suggested that water was moving through the crevices, perhaps along piping channels.

During the 2012summer, complex networks of dark green vegetation separated by gray patches of nearly bare 
ground were observed. These lines of vegetation, often forming complex polygonal patterns with dominant directional orientations, were most pronounced in fields sown with alfalfa, and to a lesser extent, soy beans and corn. The alfalfa forming the lines tended to grow more densely, taller $(0.5 \mathrm{~m}$ vs $0.15 \mathrm{~m})$, and darker/greener than those in adjacent areas. Alfalfa is typically grown on relatively steep slopes to retard soil erosion. These features were visible on Google Earth imagery acquired in September 2012 (Figure 4).
Alfalfa is described by the Soil and Health Library (2012) as follows: "Alfalfa is a long-lived, very deeply rooted perennial. Upon germination, a strong taproot develops rapidly and penetrates almost vertically downward. It often reaches a depth of 1.5 to $1.8 \mathrm{~m}$ the first season, 3.0 to $3.6 \mathrm{~m}$ by the end of the second year, and may ultimately extend to depths of $6.1 \mathrm{~m}$ or more. It is notably a deep feeder." Consequently, the alfalfa roots can access the moisture/water moving through bedrock crevices near the top of the karst aquifer. Corn

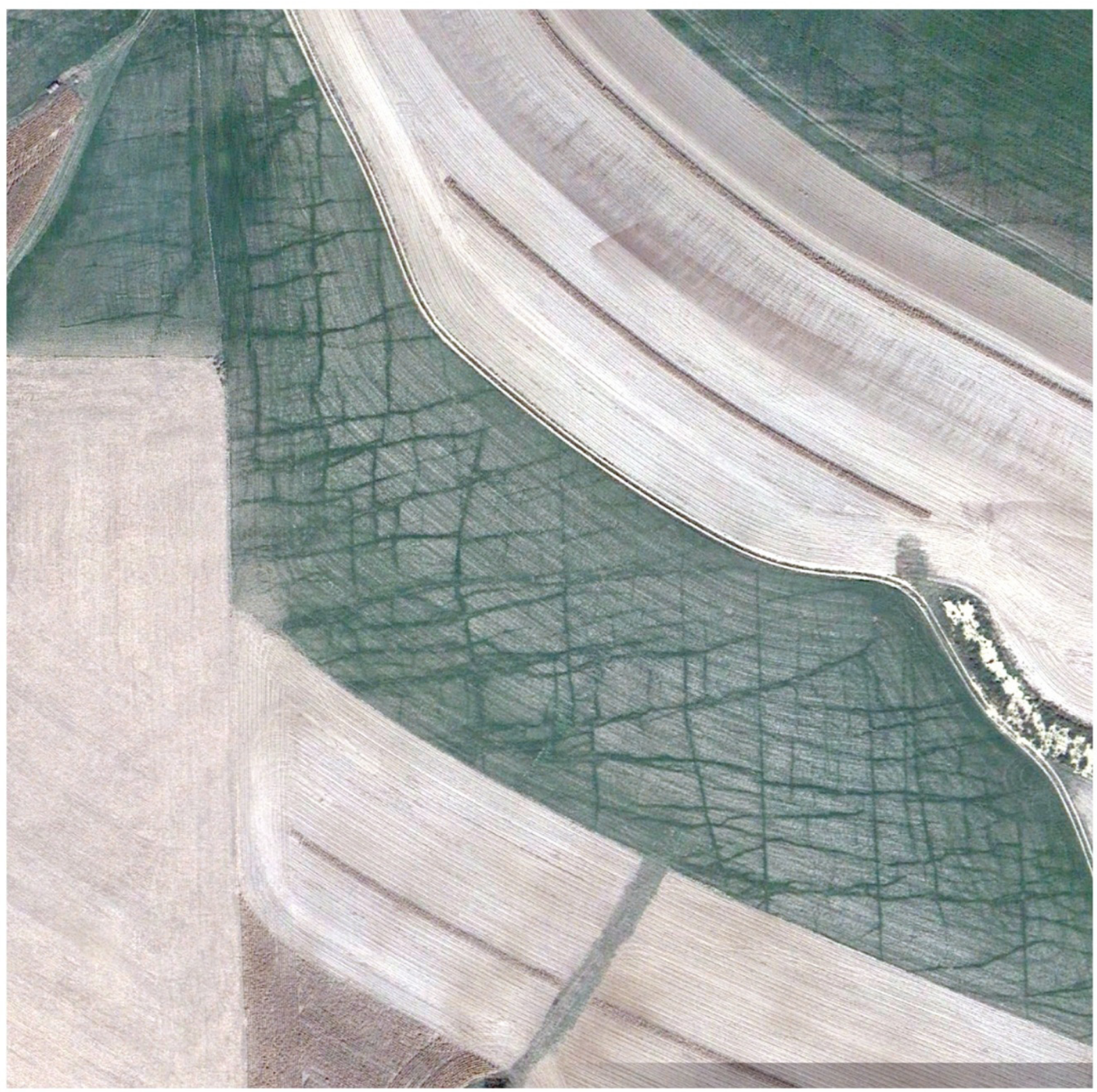

Figure 4. Google Earth imagery showing the complex geometry of crop lines in an alfalfa field. 
and soybean roots tend to have shallower root systems. Corn is a more shallow rooted plant reaching depths of $1.2 \mathrm{~m}$ or more. Less than $10 \%$ of the water taken up by the corn plant is acquired below $1 \mathrm{~m}$ (McWilliams et al. 2004). Soybean plant roots extend to a depth of 1.2 to 2.4 $\mathrm{m}$, with most of the roots being in the upper 0.15 to 0.30 m of soil (North Dakota State University 1997).

The bedrock fractures and crevices provide the necessary moisture to sustain the overlying healthy plants, while the remaining area of the field exhibits stunted and sparse plant growth. In aerial view, the crop lines create polygonal patterns, most of which trend roughly northsouth and east-west; the trends of these lines are similar to the angular lines of the adjacent streams showing rectangular drainage patterns. Rectangular stream patterns like these are well known and due to control by crevice/fracture patterns in the top of bedrock. Streams tend to follow the paths of least resistance. The orientation of the stream channel is consistent with the orientation of crop lines and the straight reaches of the stream follow trends seen in crevices exposed in outcrops, road cuts and quarries (Figure 5). This and the similarity of crop lines with lineament patterns in LiDAR elevation data, and crevice occurrence in outcrops, road cuts, and quarries found throughout eastern Jo Daviess County, western Stephenson County, and northern Carroll County indicate that the lines and patterns observed in the croplands are a direct reflection of the creviced pattern of the underlying karst aquifer. As such, the lines are a surrogate for the solution-enlarged crevices of the underlying carbonate bedrock and reveal the degree and extent of karstification in the eastern part of Jo Daviess County.

Finally, desiccation cracks are almost exclusively located along the crop lines and follow their trends (Figure 6). No cracks in the soil were seen in areas adjacent to the lines where vegetation was stunted and typically about 6 inches high. This phenomenon is probably due to fact that the shallow roots of the crops tend to take up moisture from the soil and create desiccation cracks, but only in those areas were vegetation is thriving.

\section{Ongoing Research}

The authors are currently georeferencing and analyzing crop-line length, width, and orientations in detail at sixteen sites in eastern Jo Daviess County, and their relationship with the geometry of solution-enlarged

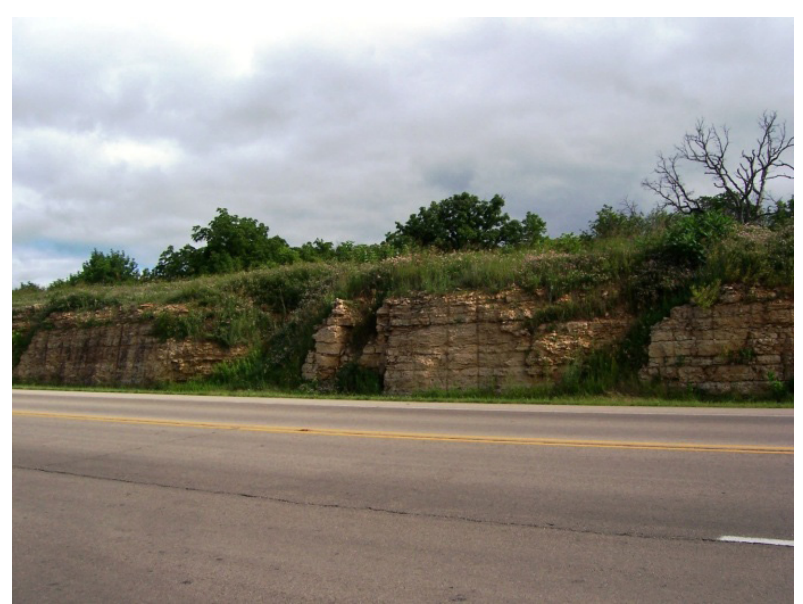

Figure 5. Road cut through Galena Dolomite and located along Rt. 20 near Elizabeth, IL in Jo Daviess Co. The solution-enlarged crevices are oriented N-S and are $1 \mathrm{~m}$ wide (from Panno et al. in review).

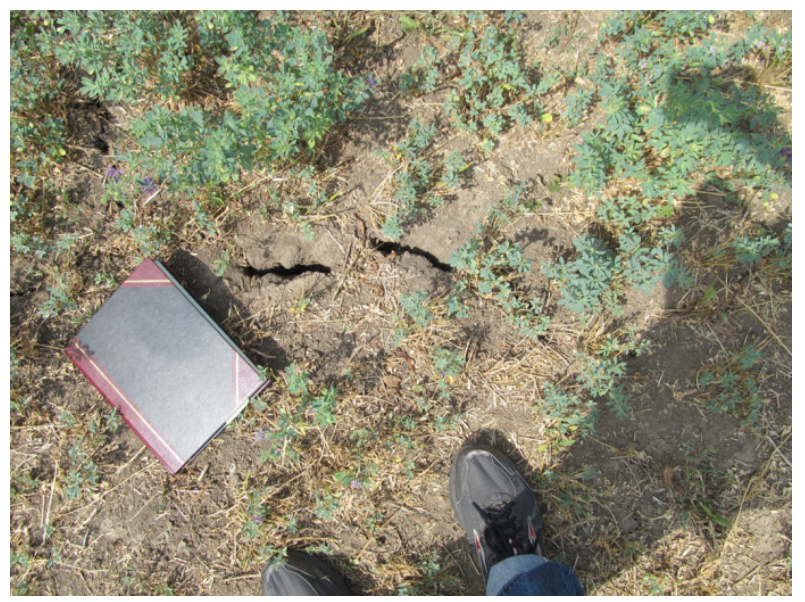

Figure 6. Desiccation cracks within and following the trends of the crop lines.

crevices. Preliminary results indicate that the crop lines are dominated by a set of fractures/crevices trending $\mathrm{N} 5^{\circ} \mathrm{E}$ and $\mathrm{N} 80-85^{\circ} \mathrm{W}$ (approximately north-south and east-west) with occasional cross-cutting fractures, crevices and zones that appear to have been shattered. The east-west trending lines are consistent with tension joints, and the north-south lines are consistent with the shear joints both identified by Heyl et al. (1959). Heyl et al. (1959) further stated that these fractures/crevices extend to a depth of up to $100 \mathrm{~m}$. The trends of the crop lines, tension and shear joints are similar to those of lineaments identified from LiDAR elevation data in the same area by Panno et al. (in review). The trends of the LiDAR elevation data lineaments are $\mathrm{N} 20^{\circ} \mathrm{W}$, and $\mathrm{N}$ $70^{\circ} \mathrm{W}$ and $\mathrm{N} 70^{\circ} \mathrm{E}$; their traces coincide with karst features (cutters and grikes, cover-collapse sinkholes, caves and springs) throughout eastern Jo Daviess County. 
Based on the presence and orientations of the crop lines and their relationship to solution-enlarged creviced seen in road cuts, quarries, and outcrops, and lineaments seen in LiDAR elevation data, it is clear that the patterns observed in the crops mimic the fracture/crevice patterns of the bedrock surface. The widths and extent of the lines may be used as a surrogate for the karst features present on the bedrock surfaces. Crop lines, coupled with solution-enlarged crevices seen in the aforementioned bedrock exposures, yield orientations and spacing of solution-enlarged crevices and fractures of the carbonate bedrock. Taken together, these features yield a three-dimensional view of the bedrock crevice-fracture system, and ultimately could provide a more complete and accurate model of the karst aquifer in the study area and similar karst areas throughout the world.

\section{Conclusions}

An investigation of crop lines that appeared during the extreme drought of the 2012 summer in the Midwestern United States may provide an additional method for investigating and characterizing karst terrains. The crop lines were noticed by local farmers primarily in alfalfa fields and reported to the ISGS in the summer of 2012. Within days, the crop lines on the ground and from aerial photography. The widths, orientations, and distance of separation of the lines were examined and compared with crevices in outcrops, road cuts and quarries, as well as with lineaments observed in LiDAR elevation data. Subsequent field work focused on character, thickness, and composition of the materials within the crevices.

The crop lines formed in very shallow soils (less than about $1.5 \mathrm{~m}$ thick) and are of similar orientation as those of solution-enlarged crevices exposed in outcrops, road cuts, and quarries, and of lineaments seen in LiDAR elevation data of the study area (roughly north-south and east-west). The limited number of crevices examined beneath the thin soils contained clays similar to those of weathered Maquoketa shale. It is likely that these clays have entered the crevices in the upper part of the Galena Dolomite. However, abundant water present within the clay suggests there is piping and movement of recharge and groundwater through the clay.

We conclude that the crop lines may be used as a surrogate for mapping the fracture/crevice pattern on the carbonate bedrock surface. The crop lines are of similar orientation as those of solution-enlarged crevices exposed in outcrops, road cuts, and quarries, and of lineaments seen in LiDAR elevation data of the study area. Crop lines, combined with other data from outcrops, road cuts, quarries and LiDAR elevation data, may be used to identify and characterize the degree and extent of karstification in the carbonate terrain of the Driftless Area on northwestern Illinois, and other karst areas of similar geology. Further research currently is underway.

\section{Acknowledgements}

We thank Jeff Kromer of Mount Carroll, IL for the generous giving of his time, skills and aircraft while flying the lead author over eastern Jo Daviess County in order to acquire reconnaissance aerial photography. Finally, we thank Amy Eller of the Illinois Department of Transportation for contributing the Aerial Survey Division resources to acquire the vertical aerial photography in a timely manner.

\section{References}

Bradbury, J.C. 1959. Crevice lead-zinc deposits of northwestern Illinois. Illinois State Geological Survey Report of Investigation 210. 49 p.

Brannon, J.C., F.A. Polosek and R.K. McLimans. 1992. Alleghenian age of the Upper Mississippi Valley zinc-leak deposit determined by Rb-Sr dating of sphalerite. Nature, v. 356, p. 509-511.

Hansel, A.K. and E.D. McKay. 2010. Quaternary period. In Geology of Illinois (D.R. Kolata and C.K. Nimz, eds.) p. 216-247.

Heyl, A.V., Jr., A.F. Agnew, E.J. Lyons and C.H. Behre, Jr. 1959. The geology of the upper Mississippi Valley zing-lead district. U.S. Geological Survey Professional Paper 309, p. 62-63.

Lattman, L.H. and R.R. Parizek. 1964. Relationship between fracture traces and the occurrence of ground-water in carbonate rock. Journal of Hydrology, v. 2, p. 73-91.

McGarry, C.S. 2000. Bedrock geology map of Jo Daviess County, Illinois. Illinois State Geological Survey Open File Series OFS 2000-8h. 1: 62,500 scale.

McWilliams, D.R. Berglund and G.J. Endres. 2004. Soybean growth and management quick guide. North Dakota State University. A-1174. Available from: $\quad$ http://www.ag.ndsu.edu/pubs/plantsci/ rowcrops/a1174/a1174w.htm.

Nelson, J.W. 1995. Structural features in Illinois. Illinois State Geological Survey ISGS Bulletin 100. 144 p.

North Dakota State University. 1997. Corn production guide. North Dakota State University. A-1130. Available from: http://www.ag.ndsu.edu/pubs/ plantsci/rowcrops/a1130-8.htm. 
Pannalal, S.J., D.T.A. Symons and D.F. Sangster. 2004. Paleomagnetic dating of Upper Mississippi Valley lead-zinc mineralization, WI, USA. Journal of Applied Geophysics, v. 56, p. 135-153.

Panno, S.V., D.E. Luman, W.R. Kelly, T.H. Larson and S.J. Taylor. 2013. Karst terrains of Northwestern Illinois' Driftless Area, Jo Daviess County. Illinois State Geological Survey Circular. In review.

Parizek, R. 1976. on the nature and significance of fracture traces and lineaments in carbonate and other terrains. Proceedings of the U.S.-Yugoslavian Symposium, Dubrovnik, June 2-7, 1975. Karst Hydrology, V. 1, V. Yevjevich, ed., Water Resources Publications, Fort Collins, CO.

Quinlan, J.F., P.L. Smart, G.M. Schindel, E.C. Alexander Jr., A.J. Edwards, A.R. Smith. 1991. Recommended administrative/regulatory definition of karst aquifer, principles of classification of carbonate aquifers, practical evaluation of vulnerability of karst aquifers, and determination of optimum sampling frequency at springs. Proceedings of the Third Conference on Hydrogeology, Ecology, Monitoring, and Management of Ground Water in Karst Terranes (1991), p. 573-635.

Riggs, M.H. and C.S. McGarry. 2000. Map showing thickness of Quaternary deposits, Jo Daviess County, Illinois. Illinois State Geological Survey Open File Series 2000-8c.

Soil and Health Library, 2012. Root habits of alfalfa. Chapter XIII. Available from: http://www. soilandhealth.org/01aglibrary/010139fieldcroproot s/010139ch13.html.

Weibel, C.P. and Panno, S.V. 1997. Karst terrains and carbonate bedrock of Illinois. Illinois State Geological Survey, Illinois Map Series 8, 1:500,000 Scale. 
